\title{
ANTIPLAQUE AND ANTIGINGIVITIS EFFECTS OF A GEL CONTAINING PUNICA GRANATUM LINN EXTRACT. A DOUBLE-BLIND CLINICAL STUDY IN HUMANS
}

\author{
EFEITO ANTIPLACA E ANTIINFLAMATÓRIO DE UM GEL CONTENDO EXTRATO DE \\ ROMÃ. ESTUDO CLÍNICO DUPLO-CEGO EM HUMANOS
}

\begin{abstract}
Alexandre Daher Yunes SALGADO ${ }^{1}$, Juliana Lemos MAIA ${ }^{1}$, Sérgio Luís da Silva PEREIRA², Telma Leda Gomes de LEMOS ${ }^{3}$, Olívia Morais de Lima MOTA ${ }^{4}$
\end{abstract}

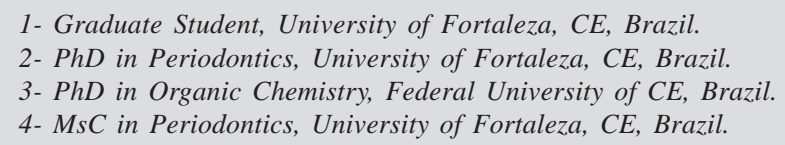

Corresponding address: Sérgio Luís da Silva Pereira - Av. Engo. Leal Lima Verde, 2086 - Alagadiço Novo - Fortaleza/CE - Cep.: 60833520 Tel: (85) 34744108 - Fax: (85) 34773059 - e-mail: luiss@unifor.br

Received: April 14, 2006 - Modification: May 11, 2006 - Accepted: June 05, 2006

\begin{abstract}
$O$ bjectives: The antiplaque and antigingivitis effects of a gel containing 10\% Punica granatum Linn extract were evaluated using a 21-day partial-mouth experimental model of gingivitis. Methods: 23 volunteers participated in this cross-over, doubleblind study, carried out in 2 phases of 21 days each. For each period of the experiment, an acrylic toothshield was made for each volunteer to carry the test or placebo gel as well as to avoid brushing of the 4 experimental teeth (posterior teeth in the lower left quadrant). The subjects were randomly assigned to use either the placebo gel (control group) or the test gel (experimental group) and were instructed to brush the remaining teeth normally 3 times a day. On days 0 and 21, the visible plaque index (VPI) and gingival bleeding index (GBI) were recorded. Results: The results did not show statistically significant difference between control and experimental groups for either of the indices (VPI and GBI). Conclusion: The gel containing 10\% Punica granatum Linn extract was not efficient in preventing supragingival dental plaque formation and gingivitis.

Uniterms: Dental plaque; Gingivitis; Punica granatum Linn.
\end{abstract}

\begin{abstract}
RESUMO
O

bjetivos: O efeito antiplaca e antigengivite de um gel contendo extrato de romã a $10 \%$ foi avaliado utilizando um modelo de gengivite experimental parcial em humanos. Métodos: 23 indivíduos participaram voluntariamente deste estudo cruzado, duplo-cego, compreendendo dois períodos de 21 dias cada um. Uma moldeira de acrílico foi confeccionada para cada participante, a qual foi utilizada como carreadora dos géis sobre a área a ser avaliada (hemiarco inferior esquerdo). Os sujeitos foram aleatoriamente designados para usar o gel placebo (grupo controle) ou o gel teste (grupo experimental), sendo instruídos a colocar o gel na moldeira e esta sobre os dentes teste, escovando os outros normalmente três vezes ao dia. No dia 0 e dia 21 os índices de placa visível (IPV) e índice de sangramento gengival (ISG) foram registrados. Resultados: Os resultados não demonstraram diferença estatística significante entre os grupos controle e experimental para nenhum dos índices. Conclusões: O gel contendo extrato de romã a $10 \%$ não foi eficiente em evitar a formação de placa bacteriana supragengival e prevenir a inflamação gengival.

Unitermos: Placa bacteriana; Gengivite; Punica granatum Linn.
\end{abstract}




\section{INTRODUCTION}

Gingivitis is a chronic inflammatory process limited to the gingiva and without either attachment or alveolar bone loss. It is one of the most frequent oral diseases, affecting more than $90 \%$ of the population, regardless of age, sex or race. The earliest clinical sign is the bleeding caused by a vasodilatory effect caused by an inflammatory response ${ }^{29}$. The prevention of gingivitis by daily and effective supragingival plaque control using toothbrushing and dental floss is necessary to arrest a possible progression to periodontitis ${ }^{3,11}$.

Although mechanical plaque control methods have the potential to maintain adequate levels of oral hygiene, clinical experience and population-based studies have shown that such methods are not being employed as accurately as they should by a large number of people. Therefore, several chemotherapeutic agents such as triclosan, essential oils and chlorhexidine have been developed to control bacterial plaque, aiming at improving the efficacy of daily hygiene control measures ${ }^{6,8,10,15-17,23,26}$

The interest in plants with antibacterial and antiinflammatory activity has increased as a consequence of current problems associated with the wide-scale misuse of antibiotics that induced microbial drug resistence ${ }^{7,18}$. Natural products such as Astronium urundeuva, calendula, aloe vera, curcuma zedoaria and other herbal products have been tested with effective results ${ }^{12,19,25,29}$. Punica granatum Linn (family Punicaceae), mostly known as "pomegranate", is a shrub or small tree native from Asia where several of its parts have been used as an astringent, haemostatic as well as for diabetes control ${ }^{5,13,24}$. In Brazil, the fruit of this tree is known as "romã" and is commonly used for treatment of throat infections, coughs and fever due to its antiinflammatory properties ${ }^{13,14}$.

In the only study available evaluating the effects of pomegranate on gingivitis, Pereira and Sampaio ${ }^{21}$ (2003) showed a significant reduction of gingival bleeding after using a dentifrice containing pomegranate extract. However, a control group was not included in that study. Therefore, the purpose of the present investigation was to assess the effects of Punica granatum Linn extract on supragingival plaque formation and development of experimental gingivitis in comparison to a control formulation.

\section{MATERIAL AND METHODS}

\section{Subjects}

Twenty-five dental students from the University of Fortaleza (UNIFOR) (12 male and 13 female aged 22 to 28 years) were enrolled in this study. All subjects had at least 20 natural teeth, among which the 4 posterior teeth in the lower left quadrant (experimental teeth). All participants, randomly screened, were informed about the nature of the study and signed an informed consent form in compliance with the guidelines of the Brazilian Health Council. Students with medical disorders, severe periodontal disease and under antimicrobial therapy, as well as smokers, pregnant women and individuals presenting a probing depth $\geq 3 \mathrm{~mm}$ associated with any mandibular teeth were excluded from the trail. The protocol was approved by the University's Ethics Committee (Report COÉTICA/Unifor)

\section{Toothshield fabrication}

An alginate impression of the experimental teeth was taken and poured in die stone to obtain casts. On each stone cast, a 0.3-mm-thick thermoplastic mouthguard material spacer was made using a vacuum former. Upon the spacer, an individual toothshield was made of a 2-mm-thick thermoplastic mouthguard material, using the same vacuum former. The toothshield was trimmed $2 \mathrm{~mm}$ beyond the gingival margin to assure that gel would be in contact with the gingival margin of the experimental teeth during toothbrushing of the remaining teeth.

\section{Test and control products}

The control and experimental gels were formulated and packed into tubes in a commercial drugstore. The tubes were previously coded to warrant that neither the examiner nor the volunteers knew their content, which was revealed by the pharmacist only after the study was completed. All students used both gels in alternate periods, according to a cross-over model.

\section{Preparation of Punica granatum Linn extract}

Fresh pomegranates were obtained in grocery stores and then barks and juice were separated. The barks were dried at room temperature during 5 days and then powdered. An infusion was prepared with powdered material at a ratio of $100 \mathrm{~g}$ powder to $1000 \mathrm{~mL}$ distilled water, cooled at room temperature and filtered. Thereafter, $50 \mathrm{~g}$ of carboxymethylcellulose was added to the infusion $(1000 \mathrm{~mL})$ and the mixture was kept boiling until complete dissolution to obtain the $10 \%$ gel concentration. The pomegranate extract concentration used in this work was based on the findings of previous in vitro studies ${ }^{13,20}$ that tested the gel at different concentrations and found that the $10 \%$ concentration yielded the most favorable results. A glycerin/ ethanol mixture (50 mL:50 mL) was added and the solution was vigorously stirred during 15 minutes until gel formation. A very small amount of menthol (flavoring) and a conserving agent were then added. The control gel had the same formulation except for the Punica granatum Linn infusion.

\section{Clinical design}

This study was a randomized, double-blind comparison of 2 crossover groups of dental students performed in 2 experimental phases of 21 days each with a 1 -month washout interval between them. A partial mouth experimental model was used ${ }^{27}$. To standardize the groups, the students were submitted to a meticulous evaluation (pre-experimental phase) to score the Visible Plaque Index (VPI) and the Gingival Bleeding Index $(\mathrm{GBI})^{1}$ of each tooth. All teeth of each subject were polished and flossed by the examiner to eliminate plaque remnants. The importance of oral hygiene was strongly reinforced. 
Thirty days after the initial phase, the volunteers were randomly assigned to 2 groups and the experimental phase began. On day 0 of both experimental periods, VPI and GBI were recorded. A personal "kit" containing a toothshield, a tube with $90 \mathrm{~g}$ of control or experimental gel and a commercial dentifrice with no antigingivitis properties (Sorriso, Kolynos do Brazil Ltda., Osasco, SP, Brazil) was given to all students. During each 21-day experimental period, the subjects were instructed to fill the toothshield with the gel prior to insertion in the mouth and seat it over the experimental teeth for at least $1 \mathrm{~min}$. The volunteers refrained from brushing the test quadrant, while the other teeth were normally brushed three times a day using the dentifrice (same to all students). In addition to verbal instructions, the subjects were given written recommendations to follow at home. On the last day of each period (21st day), VPI and GBI indexes were recorded and the teeth were polished with pumice.

\section{Clinical assessment}

VPI and GBI indexes were recorded by the same examiner on the mesiobuccal, buccal, distobuccal, mesiolingual, lingual and distolingual surfaces of the experimental teeth. The gingival tissues were inspected for the presence of bleeding, recorded 10 seconds after running the tip of a WHO probe along the gingival margin ( 0.5 -mm penetration into the sulci). The values of six sites of each tooth were recorded to obtain the VPI and GBI means. Then, VPI and GBI means for the four test teeth were calculated to determine VPI and GBI means of each volunteer. Intraexaminer agreement for VPI and GBI was calculated by repeating the measurements in 10 patients, with at least 1 hour of interval ${ }^{4}$. The Kappa coefficient was used to verify the agreement between the examinations. VPI and GBI means were 0.78 and 0.85 , respectively.

\section{STATISTICALANALYSIS}

The Mann-Whitney non-parametric test was used to evaluate statistical differences between control and experimental groups on days 0 and 21 . In each group, the mean scores of VPI and GBI were compared between baseline and the end of the trial by the Wilcoxon test. Results were expressed as means and standard deviation.

TABLE 1- Plaque index (VPI) means and standard deviation on day 0 and day 21 for the control and experimental groups

\begin{tabular}{lcc}
\hline & Control & Experimental \\
\hline Day 0 & $0.037 \pm 0.085 \mathrm{~A}, \mathrm{a}$ & $0.034 \pm 0.060 \mathrm{~A}, \mathrm{a}$ \\
Day 21 & $0.740 \pm 0.290 \mathrm{~A}, \mathrm{~b}$ & $0.770 \pm 0.270 \mathrm{~A}, \mathrm{~b}$ \\
\hline
\end{tabular}

*means followed by the same uppercase letters on day 0 and day 21 do not differ statistically ( $p>0.05)$

**means followed by different lowercase letters in a same column differ statistically $(p<0.05)$

\section{RESULTS}

Twenty-three subjects completed the clinical trial. Two students were excluded from the study during the experimental phase due to third molar extraction and restorative needs. The experimental gel had good acceptance and did not show adverse effects, such as abscess, ulcerations or allergic reactions.

On day 0 , in both experimental periods, minimum plaque and bleeding scores were present and tended to zero. The control and experimental groups did not show statistically significant difference to each other with respect to VPI $(\mathrm{p}=0.5385)$ and $\mathrm{GBI}(\mathrm{p}=0.3392)$ means $(\mathrm{p}>0.05)$. These results indicated that both groups were well balanced at baseline (Table 1 and 2). At the 21st day, plaque $(\mathrm{p}=0.4354)$ and gingival bleeding $(\mathrm{p}=0.4685)$ were present in both groups, but the difference between them was not statistically significant (Table 1 and 2).

Comparing the means between day 0 and day 21 in each group, there was a statistically significant difference in the $\operatorname{VPI}(\mathrm{p}=0.0000)$ and $\mathrm{GBI}(\mathrm{p}=0.0001)$ indexes.

\section{DISCUSSION}

The inability of adult population to perform adequate mechanical toothcleaning has stimulated the search for chemotherapeutic agents added to dentifrices to improve plaque control and prevent gingivitis ${ }^{16}$. Phytotherapic products have been investigated with these purposes and have shown satisfactory results ${ }^{12,19,29}$

The antibacterial activity of Punica granatum Linn has been evaluated in previous studies with good results. Trivedi and $\mathrm{Kazmi}^{28}$ (1979), using extracts of fruit barks have observed an antibacterial activity of pomegranate extract against Bacillus anthracis and Vibrio cholerae while Machado, et al. ${ }^{14}$ (2003) showed similar effect against Staphylococcus aureus, in agreement with Prashant and Asha $^{22}$ (2001).

Considering that flavoring agents can promote a moderate antiplaque effect ${ }^{16}$ and that the contents of test and control gels were different only with respect to the presence of pomegranate extract, this agent did not have additional effect in reducing dental plaque formation. These data are not in agreement with those of a previous in vitro

TABLE 2- Bleeding index (GBI) means and standard deviation on day 0 and day 21 for the control and experimental groups

\begin{tabular}{lcc}
\hline & Control & Experimental \\
\hline Day 0 & $0.003 \pm 0.017 \mathrm{~A}, \mathrm{a}$ & $0.008 \pm 0.017 \mathrm{~A}, \mathrm{a}$ \\
Day 21 & $0.160 \pm 0.140 \mathrm{~A}, \mathrm{~b}$ & $0.120 \pm 0.090 \mathrm{~A}, \mathrm{~b}$ \\
\hline
\end{tabular}

*means followed by the same uppercase letters on day 0 and day 21 do not differ statistically ( $p>0.05)$

**means followed by different lowercase letters in a same column differ statistically $(p<0.05)$ 
study ${ }^{20}$ that showed that a bacterial strain present in supragingival plaque, namely Streptococcus sanguis, was sensitive to different concentrations of pomegranate extract, which demonstrated an inhibitory action similar to that of chlorhexidine ${ }^{2,9}$. It should be highlighted, however, that in vitro studies do not reproduce exactly the oral conditions.

In the present study, the Punica granatum Linn extract gel did not avoid plaque formation during the trial, as suggested by Kakiuchi, et al. ${ }^{9}$ (1986) and Pereira, et al. ${ }^{20}$ (2001). As the gel was placed into on the toothshield in a non-diluted form, it may be speculated that gel solubilization by saliva would be necessary for its antimicrobial action to take place ${ }^{17}$. The antibacterial agents present in pomegranate - the hydrolysable tannins - form complexes of high molecular weight with proteins soluble, increase bacterial lysis and moreover interfere with bacterial adherence mechanisms to tooth surfaces ${ }^{9,13-14}$.

There was no significant difference between the experimental and control groups in relation to GBI at the end of the trial. These results are not consistent with those reported by Pereira and Sampaio ${ }^{21}$ (2003), who showed a significant reduction on gingivitis in patients using a dentifrice containing pomegranate extract. Nevertheless, it is noteworthy that a control group was not included in that study, which does not allow accessing the actual gingivitis reduction rate related exclusively to mechanical plaque control.

According to Ross, et al. ${ }^{24}$ (2001) the antiinflammatory effect of pomegranate may be attributed to its considerable immunoregulatory activity over macrophages and $\mathrm{T}$ and $\mathrm{B}$ lymphocyte subsets. However, in both experimental and control groups, there was a significant increase in marginal bleeding, showing that pomegranate did not avoid the development of gingivitis. The binary score used in this study only evaluate the presence or absence of bleeding; it does not allow the assessment of other characteristics of the inflammatory process, such as edema, changes in gingival contour and loss of tissue attachment. Therefore, the possible effect of Punica granatum Linn extract on controlling the severity of gingivitis cannot be discussed.

Due to the lack of clinical trials with a similar design investigating the effect of pomegranate on gingivitis, the data of this study were evaluated by parallel inferences, taken off from non specialized articles. Therefore, more controlled trials using different concentrations of Punica granatum Linn extract are necessary to verify its action upon supragingival microflora in vivo and established gingivitis. Further research will be important to identify the real benefits of pomegranate as a therapeutic and preventive agent for gingivitis, in addition to its common use in popular medicine.

\section{CONCLUSION}

Within the limits of this clinical study, it may be concluded that the gel containing $10 \%$ Punica granatum Linn extract was not efficient in preventing supragingival dental plaque formation and gingivitis.

\section{ACKNOWLEDGEMENTS}

The authors would like to thank the dental students from the Faculty of Dentistry of UNIFOR who participated in this study and Francisco Carlos L. Andrade for gel preparation.

\section{REFERENCES}

1- Ainamo J, Bay I. Problems and proposals for recording gingivitis and plaque. Int Dent J. 1975;25:229-35.

2- Anesini C, Perez C. Screening of plants used in Argentine Folk Medicine for antimicrobial activity. J Ethnopharmacol. 1993;39:11928.

3- Bakdash B. Current patterns of oral hygiene product use and practices. Periodontol 2000. 1995;8:11-4.

4- Blieden TM. Caton JG, Proskin HM, Stein SH, Wegener CJ. Examiner reliability for an invasive gingival bleeding index. J Clin Periodontol. 1992;19:262-7.

5- Das AK, Mandal SC, Banerjee SK, Sinha S, Saha BP, Pal M. Studies on the hypoglycaemic activity of Punica granatum seed in streptozotocin induced diabetic rats. Phytotherapy Res. 2001;15:6289

6- De Paola LG. Chemotherapeutic inhibition of supragingival dental plaque and gingivitis development. J Clin Periodontol. 1989;16:3115

7- Emori TG, Gaynes RP. An overview of nosocomial infections including the role of the microbiology laboratory. Clinical Microbiologica Review. 1993;6:428-42.

8- Gordon J, Lamster I, Seiger M. Efficacy of Listerine antiseptic in inhibiting the development of plaque and gingivitis. J Clin Periodontol. 1985;12:697-704.

9- Kakiuchi N. Studies on dental caries prevention by traditional medicines. VIII. Inhibitory effect of various tannins on glucan synthesis by glucosyltransferase from Streptococcus mutans. Chem Pharmacol Boll. 1986;34:720-5.

10- Lindhe J, Rosling B, Socransky SS, Volpe AR. The effect of a triclosan-containing dentifrice on established plaque and gingivitis. $\mathrm{J}$ Clin Periodontol. 1993;20:327-34.

11- Löe H, Theilade E, Jensen SE. Experimental gingivitis in man. J Periodontol. 1965:36:177-87.

12- Lorenzo MRO, Madrigal GR, Pineda JP. Efectos de la tintura de calêndula al 10 porciento en adolescentes afectados por gingivitis crónica. MediCiego. 1997;3:33-6.

13- Machado TB, Leal ICR, Amaral ACF, Santo KRN, Silva MG, Kuster RM. Antimicrobial ellagitannin of Punica granatum fruits. J Braz Chem Soc. 2002;13: 606-10.

14- Machado TB, Pinto MCFR, Leal ICR, Silva MG, Amaral ACF, Kuster RM, Netto-dos-Santos KR. In vitro activity of Brazilian medicinal plants, naturally occurring naphthoquinones and their analogues, against methicillin-resistant staphylococcus aureus. Int J Antimicrob Agents. 2003;21:279-84.

15- Marsh PD. Dentifrices containing new agents for the control of plaque and gingivitis: microbiological aspects. J Clin Periodontol. 1991;18:462-7. 
16- Nogueira-Filho GR, Toledo S, Cury JA. Effect of 3 dentifrices containing triclosan and various additives. An experimental gingivitis study. J Clin Periodontol. 2000; 27:494-8.

17- Palomo F, Wantland L, Sanchez A, Volpe AR, McCool J, DeVizio W. The effect of three commercially available dentifrices containing triclosan on supragingival plaque formation and gingivitis: a six month clinical study. Int Dent J. 1994;44:75-81.

18- Pannuti CS, Grinbaum RS. An overview of nosocomial infection control in Brazil. Infectol Contr Hosp Epidemiol. 1995;16:170-4.

19- Pannuti CM, Mattos JP, Ranoya PN, Jesus AM, Lotufo RFM, Romito GA. Clinical effect of a herbal dentifrice on the control of plaque and gingivitis. A double-blind study. Pesqui Odontol Bras. 2003;17(4):314-8.

20- Pereira JV, Silva SC, Filho LS, Higino JS. Atividade antimicrobiana do extrato hidroalcoólico da Punica granatum Linn sobre microorganismos formadores de placa bacteriana. Rev Periodontia. 2001;12:57-64.

21- Pereira JV, Sampaio FC. Estudos com o extrato da punica granatum linn (romã): efeito antimicrobiano in vitro e avaliação clínica de um dentifrício sobre microorganismos do biofilme dental [abstract]. Jornal da Aboprev. 2003;Fev-abr:8.

22- Prashant D, Asha MK, Amit A. Antibacterial activity of Punica granatum. Fitoterapia. 2001;72:171-3.

23- Renvert S, Birkhed D. Comparison between 3 triclosan dentifrices on plaque, gingivitis and salivary microflora. J Clin Periodontol. 1995;22:63-70.

24- Ross RG, Selvasubramanian S, Jayasundar S. Immunomodulatory activity of Punica granatum in rabbits-a preliminary study. J Ethnopharmacol. 2001; 78:85-7

25- Sandrini JC, Navarro DF, Rocha JCF, Ribeiro PG, Koslowsky Jr. VA. Efeitos do extrato de curcuma zedoaria sobre a placa dental e gengivite em humanos - avaliação clínica. Rev Periodontia. 1997;6:37.

26- Svatun B, Saxton CA, Huntington E, Cummins D. The effects of three silica dentifrices containing Triclosan on supragingival plaque and calculus formation and gingivitis. Int Dent J. 1993;43(1):44152 .

27- Theilade E. The experimental gingivitis studies: the microbiological perspective. J Dent Res. 1996;75:1434-8.

28- Trivedi VB, Kazmi SM. Kachnar and anar as antibacterial drugs. Ind Drugs. 1979;16: 295-8.

29- Villalobos OJ, Salazar CR, Sánchez GR. Efecto de un enjuague bucal compuesto de aloe vera en la placa bacteriana e inflamación gingival. Acta Odontol Venez. 2001;39:16-24. 